\title{
Nematode Management Using Sorghum and Its Relatives $^{1}$
}

\author{
K. Dover, K. -H. Wang, Z. J. Grabau, and R. McSorley²
}

\section{Introduction}

Sorghum (Sorghum bicolor (L.) Moench) and sorghumsudangrass (S. bicolor x S. sudanense (Piper) Stapf) are often used in crop rotation systems in Florida. Not only do they produce a source of forage or silage for animal feed, but many cultivars are effective in reducing population levels of root-knot nematodes, which are key nematode pests in Florida as well as many other parts of the world. Sorghumsudangrass ( $S$. bicolor $\mathrm{x}$ S. sudanense), also known as sorghum $\mathrm{x}$ sudangrass, sudax, or sudex, is a hybrid between sorghum (S. bicolor) and sudangrass (S. sudanense). Specific cultivars of either sorghum, sudangrass, or sudex provide a potential for nematode management, with the hybrid having more advantages over either one of its parents. This article is intended to guide agricultural professionals in making decisions about producing sorghum and its relatives for nematode management.

\section{Sorghum}

Sorghum, currently classified as S. bicolor, was formerly known as $S$. vulgare Pers. Although sorghum is often used as a forage source, sorghum grain is used as food in many countries. This grass can also be used as a source of sugar, syrup (produced from sweet sorghum types), fiber, and feed grain.
In the United States, grain sorghum is of more commercial importance than forage sorghum. Grain sorghum (Figure 1) (less than 6 feet tall) is usually shorter than forage sorghum (Figure 2) (6-15 feet), and may be planted for feed grain or silage, whereas forage sorghum is planted for silage only. Forage sorghum can produce more biomass than sudangrass, but also accumulates more prussic acid, which is harmful for livestock (Vendramini et al. 2019). For more information on forage sorghum production, see "Forage Sorghum"(Vendramini et al. 2019).

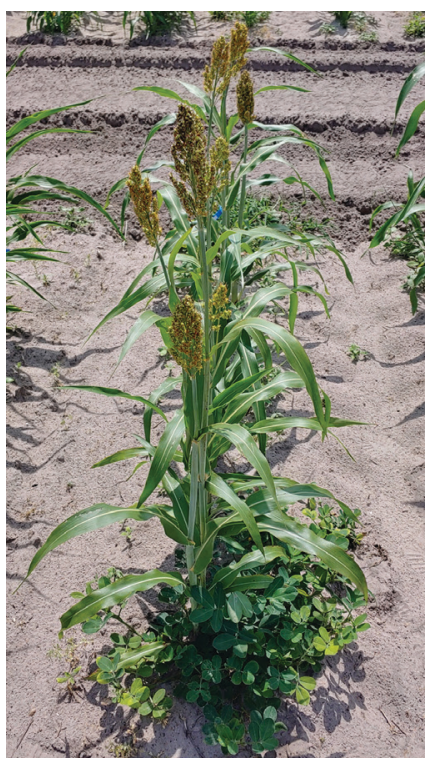

Figure 1. Grain sorghum (Sorghum bicolor) growing in a research plot. Credits: Z. J. Grabau, UF/IFAS

1. This document is ENY716, one of a series of the Entomology and Nematology Department, UF/IFAS Extension. Original publication date September 2004. Revised October 2021. Visit the EDIS website at https://edis.ifas.ufl.edu for the currently supported version of this publication.

2. K. Dover; K. -H. Wang, Department of Plant and Environmental Protection Services, University of Hawaii at Manoa; Z. J. Grabau, assistant professor, field crop nematology, Entomology and Nematology Department; and R. McSorley, professor emeritus, Entomology and Nematology Department; UF/IFAS Extension, Gainesville, FL 32611.

The Institute of Food and Agricultural Sciences (IFAS) is an Equal Opportunity Institution authorized to provide research, educational information and other services

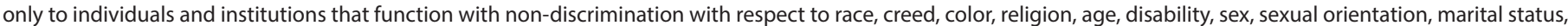

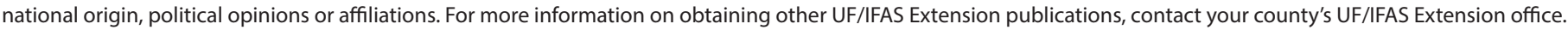
U.S. Department of Agriculture, UF/IFAS Extension Service, University of Florida, IFAS, Florida A \& M University Cooperative Extension Program, and Boards of County Commissioners Cooperating. Nick T. Place, dean for UF/IFAS Extension. 


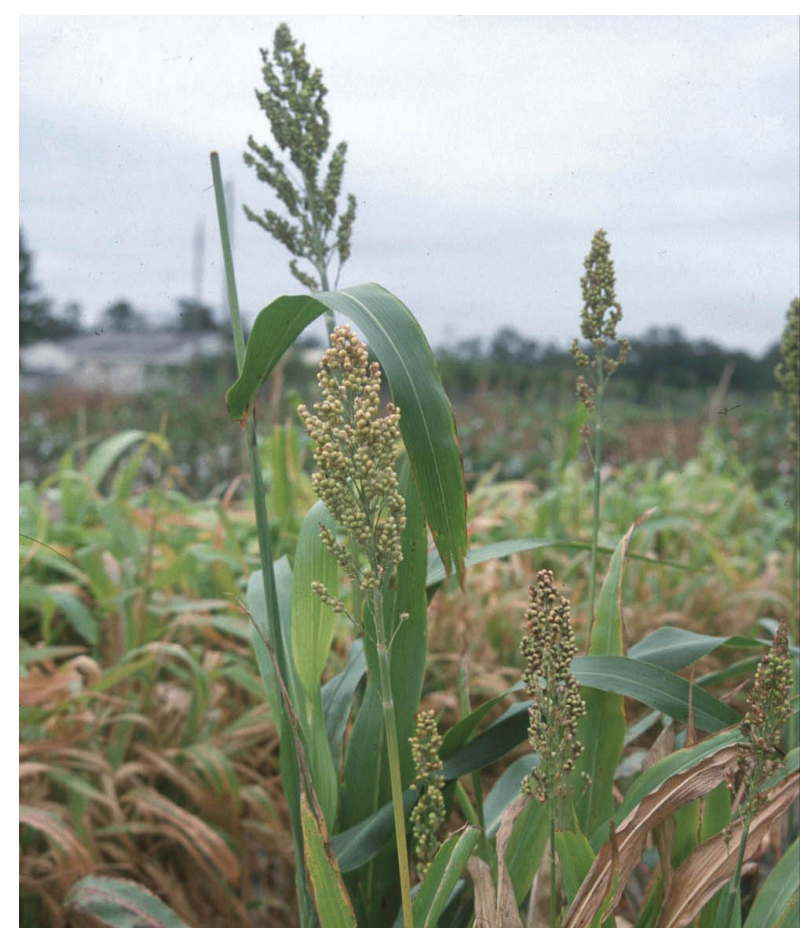

Figure 2. Forage sorghum, Sorghum bicolor. Credits: K. -H. Wang, UF/IFAS

\section{Sudangrass}

Sudangrass (Sorghum sudanense, formerly classified as $S$. vulgare var. sudanense) has high palatability and does not carry the toxicity risk to livestock and horses that forage sorghum does (Mojtahedi et al. 1993). Some varieties, most notably Trudan 8 , also have nematicidal properties. Therefore, sudangrass can be planted for forage and nematode management. Sudangrass usually grows $3-8$ feet high. It will regrow following each harvest until it is killed by cool temperatures or lack of moisture (Vendramini et al. 2019).

\section{Sorghum-Sudangrass}

Sorghum-sudangrass (Figure 3), also commonly called sudax, sudex, or sorghum $\mathrm{x}$ sudangrass (Sudax ${ }^{\circledast}$ is registered by DeKalb Genetics Corporation, De Kalb, Ilinois) is advantageous over either parent in that it produces larger quantities of biomass. It resembles sudangrass but is taller and has larger stems and leaves. Like sudangrass, the hybrid will regrow after each harvest unless it is restricted by environmental conditions. Sorghum-sudangrass roots deeply, and may even help to aerate compacted subsoils (SARE Outreach 2007). This hybrid is able to grow in soil with a $\mathrm{pH}$ range of 5.5-8.3 and is sometimes used to reclaim alkaline soil (SARE Outreach 2007). It is very drought tolerant, has high seedling vigor, and some varieties have reduced lignin content (such as the brown midrib sorghum $\mathrm{x}$ sudangrass crosses) to increase digestibility for animals and decomposition rate.

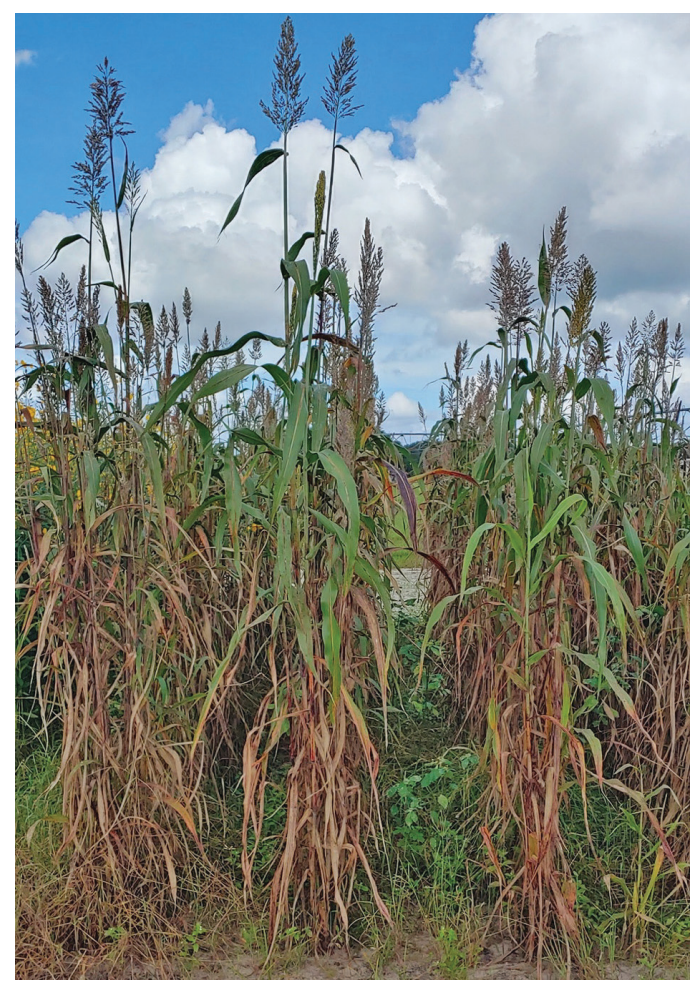

Figure 3. Sorghum-sudangrass (S. bicolor x S. sudanense). Credits: Z. Grabau, UF/IFAS

\section{Advantages as a Cover Crop}

Cover crops are crops grown between cash crop cycles to provide ground cover, reduce erosion, increase organic matter, or reduce pests. Unlike forage crops or cash crops, aboveground biomass of cover crops is not harvested, but typically incorporated into the soil either dry at maturity or green before the cover crop is mature. When the cover crop is incorporated while still green, it is known as a green manure. Whether incorporated dry or green, sorghum-sudangrass helps build up organic matter content in soil due to its rapid biomass production. Dry matter production can be as much as $8,000-10,000 \mathrm{lbs} /$ acre/year. Also, it generally does not support populations of some key nematode pests, such as root-knot nematodes (Meloidogyne spp.). In addition, sorghum-sudangrass is found to have other pest management properties listed below.

\section{Disease and Insect Management}

Certain sorghum-sudangrass varieties are not only poor hosts for root-knot nematodes, but may also be resistant to some diseases and insect pests. Resistance to downy mildew (Sclerospora sorghi), anthracnose (Collectotrichum sp.), maize dwarf mosaic virus, head smut (Sphacelotheca reiliana), and greenbug (an aphid, Schizaphis graminum) has been reported in some sorghum-sudangrass varieties. 


\section{Weed Management}

Sorghum or some other crops, including barley (Hordeum vulgare), rye (Secale cereale), sudangrass, sweet clover (Melilotus sp.), and sunflower (Helianthus spp.), can be planted to suppress weed growth (Rice 1984). These crops have traditionally been called "smother crops" because of their ability to suppress weed growth. The weed-suppressive properties of sorghum are attributed to competition and its vigorous growth habit. However, some believe that toxic substances produced by sorghum might also play a role for this weed-smothering effect (Overland 1966). For more information on weed management in sorghum, please visit http://edis.ifas.ufl.edu/WG002.

\section{Nematode Management}

Sorghum cover cropping helps manage nematodes primarily through the rotation effect. In this context, the rotation effect is a decline in nematode populations by growing a poor host or non-host of the nematodes in the particular field. This occurs because the nematodes are deprived of their food source and cannot reproduce. The host status of sorghum or its relatives for the nematode species present is the most important factor in determining if the cover crop will be effective for managing the nematodes in a given field. Therefore, efficacy of sorghum, sudangrass, or sorghum-sudangrass for nematode management depends on the target nematode and may also vary by cultivar (Table 1). Compounds toxic to nematodes and that enhance nematode antagonists-microbes or other organisms that parasitize nematodes-may also contribute to nematode management by sorghum and its relatives (Dutta et al. 2019).

In general, use of sorghum-sudangrass and its relatives improves root-knot nematode management. In Florida, 'SX-17' sorghum-sudangrass did not support reproduction of the root-knot nematodes Meloidogyne incognita (races 1 and 3), M. arenaria (race 1), or M. javanica (McSorley et al. 1994a; McSorley and Gallaher, 1991). No egg masses were found on 'SX-17' in any of the tests. In greenhouse studies, various sorghum and sorghum-sudangrass cultivars were not hosts of the invasive Meloidogyne enterolobii (de Brida et al. 2017; de Brida et al. 2018). Another study by McSorley et al. (1994b) suggested that sorghum-sudangrass 'SX-17' could be a beneficial crop for use in a rotation for the control of root-knot nematodes and yield improvement of subsequent vegetable crops.

In the northern United States, a cultivar of sudangrass (Trudan 8) suppressed the northern root-knot nematode, M. hapla, in vegetables (Widmer and Abawi 2002;
Rehiayani and Hafez 1998). In an Oregon potato trial in which sudangrass and sorghum-sudangrass residues were incorporated into the soil, the sudangrass cultivar Trudan 8 and sorghum- sudangrass hybrids Sordan 79, SS-222, and Bravo II reduced populations of Meloidogyne chitwoodi (Mojtahedi et al. 1993).

Certain cultivars, particularly of sorghum, may be hosts of some root-knot nematode species, though. In an Alabama field study, populations of Meloidogyne arenaria (root-knot nematode) juveniles in a sorghum-soybean (Glycine max) rotation were elevated above numbers found in either a soybean monoculture or a corn (Zea mays)-soybean rotation (Rodriguez-Kabana et al. 1991). In greenhouse studies, susceptibility of sorghum and sorghum-sudangrass to $M$. incognita and M. javanica varied by cultivar (de Brida et al. 2017; de Brida et al. 2018)

Sorghum-sudangrass and its relatives typically increase populations of - and may sustain damage from-nematodes that are common on grasses, including sting, stubbyroot, and lesion nematodes. Because these nematodes also damage potato, this is particularly problematic in rotations with potato in northeast Florida, where sorghumsudangrass cover cropping is common. Supplemental management, such as nematicide application, is typically required if potatoes are rotated with sorghum-sudangrass. Sting nematode (Belonolaimus longicaudatus) populations were found to be high enough to reduce yields in coolseason vegetables when planted after sorghum-sudangrass (Rhoades 1980). In rotation with cabbage and potato, sting nematode increased on sorghum-sudangrass 'SX-17' (Perez et al. 2000), and the same cultivar increased sting nematode relative to velvetbean (Crow et al. 2001). Also, stubby-root nematode populations built up when sorghum-sudangrass was used in a rotation (McSorley et al. 1994b). Sudangrass can harbor large populations of a lesion nematode (Pratylenchus penetrans) (Marks and Townshend 1973). In Florida, sorghum 'FS25E' and sorghum-sudangrass 'SX-17' did not reduce populations of other plant-parasitic nematodes such as Paratrichodorus minor (stubby root nematode), Pratylenchus scribneri (lesion nematode), or Mesocriconema spp. (ring nematodes) (McSorley and Gallaher 1991). Thies et al. (1995) found that although forage sorghum, sudangrass, and sorghum-sudangrass are all hosts for $P$. penetrans, these crops are less suitable hosts than are other forage crop species such as white clover (Trifolium repens), oat (Avena sativa), and rye. Therefore, nematode susceptibility of the subsequent crop(s) should be evaluated before deciding on a sorghum or sorghum-sudangrass rotation. 


\section{Planting Tips}

Sorghum-sudangrass is a warm season crop, and should be planted in spring to early summer (Vendramini et al. 2019). The best planting time is when soils are warm and moist. Although sorghum-sudangrass tolerates high $\mathrm{pH}$ (and moderate acidity) and low fertility, it will become better established with good fertility (with special attention paid to nitrogen) and near-neutral $\mathrm{pH}$ (SARE Outreach 2007). Sorghum-sudangrass biomass will increase with the rate of nitrogen applied. The crop can be seeded in rows or broadcast. Seeding rates may be as low as $8-20 \mathrm{lb} / \mathrm{acre}$ when grown in rows for forage production (Vendramini et al. 2019). For use in weed management or when broad coverage is desired, broadcast seeding is preferred at rates of $20-30 \mathrm{lb} /$ acre (Vendramini et al. 2019) or even $40-50$ $\mathrm{lb} / \mathrm{acre}$ as recommended by SARE Outreach (2007). See "Cover Crops" (Wright et al. 2017), "Forage Sorghum" (Vendramini et al. 2018), and "Silage Crops for Dairy and Beef Cattle"(Vendramini et al. 2019) for more information on production of sorghum and its relatives.

Sorghum-sudangrass may be interplanted (broadcast together) with legumes such as sesbania (Sesbania exaltata), forage soybean (Glycine max), or cowpea (Vigna unguiculata). However, root-knot nematodes may not be suppressed in mixed plantings with sorghum-sudangrass and could be increased if the interplanted crops are good nematode hosts.

In warmer regions where fall crops are grown, a better option may be to mow the sorghum-sudangrass and incorporate it into the soil either after maturity or as a green manure. If incorporating sorghum-sudangrass residue into the soil, it is important to break the plants into smaller pieces so decomposition will be hastened. Disking, flail chopping, or sicklebar mowing before tillage will decrease the likelihood of residue nitrogen being tied up and thus unavailable to the subsequent crop. Sudangrass has a very high C:N ratio, meaning that large amounts of biomass will take a relatively long time to be fully decomposed by soil microorganisms (SARE Outreach 2007). If residues are to be left on the soil surface (as in a no-till operation), flail chopping after the frost or using an herbicide to kill the sorghum-sudangrass is recommended (SARE Outreach 2007). If sudangrass or sorghum-sudangrass residues are to be used for suppression of nematodes or soilborne diseases, best results are obtained if the material is incorporated as a green manure (Orfonedes 1995; Widner and Abawi 2002). However, best suppression of root-knot nematodes in Florida has occurred when sorghum or sorghumsudangrass are used as rotation crops. Benefits of using the crop residues for nematode suppression in Florida are unknown and untested.

\section{Hazards when Growing Sorghum- Sudangrass}

Sorghum-sudangrass contains levels of prussic acid (hydrogen cyanide) and hordenine (an alkaloid). Prussic acid is bound to sugars within the plant, and is released during frosts, decomposition, drought stress, and mechanical damage (Vendramini et al. 2018). If using sorghum-sudangrass as forage for cattle, do not allow grazing until the plants are at least 24 inches tall because prussic acid content may be higher in younger plants (SARE Outreach 2007). Horses should never be allowed to graze on or eat hay made from sorghum-sudangrass because it may cause inflammation of the urinary tract (cystitis syndrome) (Turner 2021).

Phytotoxicity can also occur if the green manure from sudangrass is not decomposed properly. Increasing the time between incorporating green manure and planting the subsequent crop is one method to mitigate phytotoxicity. Viaene and Abawi (1998) avoided phytotoxicity by planting lettuce (Lactuca sativa) 1 month after incorporation of sudangrass. Delaying planting too long after incorporating sorghum may reduce nematode suppression as 1- or 2-month-old tissues were more effective than 3-month-old tissue of sudangrass for nematode suppression (Viaene and Abawi 1998). Therefore, proper management of the sudangrass as a cover crop is important for the best results of nematode suppression and yield improvement.

Cover cropping with sorghum in southeastern Florida aggravates problems with wireworms (Coleoptera: Elateridae), which may be problematic in potato production. Early harvest of sorghum before wireworms oviposit can alleviate this problem (Weingartner et al. 1993).

\section{Selected References}

Dutta, T. K., M. R. Khan, and V. Phani. 2019. "PlantParasitic Nematode Management via Biofumigation Using Brassica and Non-Brassica Plants: Current Status and Future Prospects." Current Plant Biology 17:17-32. https:// doi.org/10.1016/j.cpb.2019.02.001

Gallaher, R. N., R. McSorley, and D. W. Dickson. 1991. "Nematode Densities Associated with Corn and Sorghum Cropping Systems in Florida." Supplement to Journal of Nematology 23:668-672. 
Marks, C. F., and J. L. Townshend. 1973. "Multiplication of the Root Lesion Nematode Pratylenchus penetrans under Orchard Cover Crops." Canadian Journal of Plant Science 53:187-188.

McSorley, R., D. W. Dickson, and J. A. deBrito. 1994a. "Host Status of Selected Tropical Rotation Crops to Four Populations of Root-Knot Nematodes." Nematropica 24:45-53.

McSorley, R., D. W. Dickson, J. A. deBrito, and R. C. Hochmuth. 1994b. "Tropical Rotation Crops Influence Nematode Densities and Vegetable Yields." Journal of Nematology 26:308-314.

McSorley, R., D. W. Dickson, J. A. deBrito, T. E. Hewlett, and J. J. Frederick. 1994c. "Effects of Tropical Rotation Crops on M. arenaria Population Densities and Vegetable Yields in Microplots." Journal of Nematology 26:175-181.

McSorley, R., and R. N. Gallaher. 1991. "Nematode Population Changes and Forage Yields of Six Corn and Sorghum Cultivars." Supplement to Journal of Nematology 23:673-677.

McSorley, R., and R. N. Gallaher. 1993. "Population Dynamics of Plant-Parasitic Nematodes on Cover Crops of Corn and Sorghum." Journal of Nematology 25:446-453.

Mojtahedi, H., G. S. Santo, and R. E. Ingham. 1993. "Suppression of Meloidogyne chitwoodi with Sudangrass Cultivars as Green Manure." Journal of Nematology 25:303-311.

Orfanedes, M. 1995. "Sudangrass trials-What have we learned to date?” Lake Plains Vegetable Program, Cornell Cooperative Extension Program. Ithaca, NY.

Overland, L. 1966. "The Role of Allelopathic Substances in the 'Smother Crop' Barley." American Journal of Botany 53:423-432.

Rehiayani, S., and S. Hafez. 1998. "Host Status and Green Manure Effect of Selected Crops on Meloidogyne chitwoodi race 2 and Pratylenchus neglectus." Nematropica 28:213-230.

Rhoades, H. L. 1980. "Relative Susceptibility of Tagetes patula and Aeschynomene americana to Plant Nematodes in Florida." Nematropica 10:116-120.

Rice, E. L. 1984. Allelopathy. Orlando, FL: Academic Press, Inc.
Rodriguez-Kabana, R., D. B. Weaver, D. G. Robertson, C. F. Weaver, and E. L. Carden. 1991. "Rotations of Soybean with Tropical Corn and Sorghum for the Management of Nematodes." Supplement to Journal of Nematology 23:662-67.

Sustainable Agriculture Research and Education (SARE) Outreach. 2007. "Sorghum-Sudangrass Hybrids.” In "Managing Cover Crops Profitably" $3^{\text {rd }}$ Edition. Sustainable Agriculture Research and Education Program. Cooperative Research, Education and Extension Service, United States Department of Agriculture. https://www. sare.org/publications/managing-cover-crops-profitably/ nonlegume-cover-crops/sorghum-sudangrass/

Thies, J. A., A. D. Petersen, and D. K. Barnes. 1995. "Host Suitability of Forage Grasses and Legumes of RootLesion Nematode Pratylenchus penetrans." Crop Science 35:1647-1651.

Turner, J. 2021. Sorghum Cystitis Ataxia Syndrome of Horses. Las Cruces: New Mexico State University Cooperative Extension Service. Volume 63.

Vendramini, J., A. Adesogan, and J. Wasdin. 2018. Silage Crops for Dairy and Beef Cattle. SS-AGR-69. Gainesville: University of Florida Institute of Food and Agricultural Sciences. https://edis.ifas.ufl.edu/publication/aa250

Vendramini, J., E. Erickson, W. Vermerris, and D. Wright. 2019. Forage Sorghum. SS-AGR-333. Gainesville: University of Florida Institute of Food and Agricultural Sciences. https://edis.ifas.ufl.edu/publication/ag343

Viaene, N. M., and G. S. Abawi. 1998. "Management of Meloidogyne hapla on Lettuce in Organic Soil with Sudangrass as a Cover Crop." Plant Disease 82:945-952.

Weingartner, D. P., R. McSorley, and R. W. Goth. 1993. "Management Strategies in Potato for Nematodes and Soil-Borne Diseases in Subtropical Florida." Nematropica 23:233-245.

Widmer, T. L., and G. S. Abawi. 2002. "Relationship between Levels of Cyanide in Sudangrass Hybrids Incorporated into Soil and Suppression of Meloidogyne hapla." Journal of Nematology 34:16-22.

Wright, D. L., Mackowiak, C., and A. Blount. Cover crops. SS-AGR-66. Gainesville: University of Florida Institute of Food and Agricultural Sciences. https://edis.ifas.ufl.edu/ publication/AA217 
Table 1. Host status of cultivars of sorghum and sorghum-sudangrass to important plant-parasitic nematodes in Florida.

\begin{tabular}{|c|c|c|c|}
\hline \multirow{2}{*}{$\begin{array}{l}\text { Nematode (species and common } \\
\text { name) }\end{array}$} & \multicolumn{3}{|c|}{ Cultivara } \\
\hline & Poor/Non-host & Good host & Reference \\
\hline \multicolumn{4}{|l|}{ Sorghum } \\
\hline $\begin{array}{l}\text { Meloidogyne incognita (southern root- } \\
\text { knot nematode) }\end{array}$ & $\begin{array}{l}\text { 'DeKalb FS25E','DeKalb } \\
\text { BR64', + }\end{array}$ & 'Asgrow Chaparral',+ & $\begin{array}{l}\text { Gallaher et al. (1991); McSorley and } \\
\text { Gallaher (1991; 1993); de Brida et al. (2017) }\end{array}$ \\
\hline $\begin{array}{l}\text { M. javanica (Javanese root-knot } \\
\text { nematode) }\end{array}$ & + & + & de Brida et al. $(2017)^{b}$ \\
\hline $\begin{array}{l}\text { Meloidogyne enterolobii (guava root- } \\
\text { knot nematode) }\end{array}$ & + & & de Brida et al. (2018) \\
\hline $\begin{array}{l}\text { M. arenaria (peanut root-knot } \\
\text { nematode) }\end{array}$ & & + & Rodriguez-Kabana et al. (1991) \\
\hline $\begin{array}{l}\text { Belonolaimus longicaudatus (sting } \\
\text { nematode) }\end{array}$ & & 'Cargill 7993' & Todd (1991) \\
\hline Pratylenchus scribneri (lesion nematode) & & 'DeKalb BR64’ & McSorley and Gallaher (1991) \\
\hline $\begin{array}{l}\text { Paratrichodorus minor (stubby-root } \\
\text { nematode) }\end{array}$ & & + & McSorley and Gallaher (1991) \\
\hline $\begin{array}{l}\text { Mesocriconema sphaerocephala (ring } \\
\text { nematode) }\end{array}$ & & $\begin{array}{l}\text { ‘DeKalb FS25E','DeKalb BR64', } \\
\text { 'Asgrow Chaparral' }\end{array}$ & $\begin{array}{l}\text { Gallaher et al. (1991); McSorley and } \\
\text { Gallaher (1991; 1993) }\end{array}$ \\
\hline \multicolumn{4}{|l|}{ Sorghum-sudangrass } \\
\hline $\begin{array}{l}\text { Meloidogyne incognita (southern root- } \\
\text { knot nematode) }\end{array}$ & $\begin{array}{l}\text { 'SX-17', 'Sugar Grazer II', } \\
\text { 'BRS-800' }\end{array}$ & 'BRS-801','BRS-802' & $\begin{array}{l}\text { McSorley et al. (1994a, 1995); Kokalis- } \\
\text { Burelle et al. (2013); de Brida et al. (2017) }\end{array}$ \\
\hline $\begin{array}{l}\text { M. javanica (Javanese root-knot } \\
\text { nematode) }\end{array}$ & $\begin{array}{l}\text { 'SX-17,',ST6E', 'Sugar } \\
\text { Grazer II",'BRS-800' }\end{array}$ & 'BRS-801,'BRS-802' & $\begin{array}{l}\text { McSorley et al. (1994a); Kokalis-Burelle et } \\
\text { al. (2013); de Brida et al. (2017) }\end{array}$ \\
\hline $\begin{array}{l}\text { M. arenaria (peanut root-knot } \\
\text { nematode) }\end{array}$ & 'SX-17', 'Sugar Grazer II' & & $\begin{array}{l}\text { McSorley et al. (1994a, c); Kokalis-Burelle } \\
\text { et al. (2013) }\end{array}$ \\
\hline $\begin{array}{l}\text { Meloidogyne enterolobii (guava root- } \\
\text { knot nematode) }\end{array}$ & + & & de Brida et al. (2018) \\
\hline $\begin{array}{l}\text { Heterodera glycines (soybean cyst } \\
\text { nematode) }\end{array}$ & + & & Rodriguez-Kabana et al. (1991) \\
\hline $\begin{array}{l}\text { Paratrichodorus minor (stubby-root } \\
\text { nematode) }\end{array}$ & & 'SX-17', + & $\begin{array}{l}\text { McSorley et al. (1994b); McSorley and } \\
\text { Dickson (1995); Perez et al. (2000) }\end{array}$ \\
\hline $\begin{array}{l}\text { Belonolaimus longicaudatus (sting } \\
\text { nematode) }\end{array}$ & &,$+{ }^{\prime} \mathrm{SX}-17^{\prime}$ & $\begin{array}{l}\text { Rhoades (1980); McSorley and Dickson } \\
\text { (1995); Perez et al. (2000); Crow et al. } \\
\text { (2001) }\end{array}$ \\
\hline Pratylenchus spp. (lesion nematode) & & 'SX-17' & McSorley and Dickson (1995) \\
\hline Mesocriconema spp. (ring nematode) & & 'SX-17' & McSorley and Dickson (1995) \\
\hline \multicolumn{4}{|c|}{$\begin{array}{l}\text { a }+ \text { indicates result of the study cited was poor host or good host, but cultivar was not specified in the study or too many cultivars were tested } \\
\text { to list. The given nematode does not increase on a poor host, and this cultivar may be useful for managing that nematode. A good host } \\
\text { increases populations of the given nematode and is not a favorable choice for managing that nematode. } \\
\text { b Some cultivars were good hosts for M. javanica while others were poor hosts in de Brida et al. (2017) }\end{array}$} \\
\hline
\end{tabular}

